\title{
Primary angiosarcoma of the small bowel: A case report
}

\author{
Maria Olim Sousa, Ricardo Cabrita Viveiros, Diana Fernandes, \\ Rómulo Ribeiro, Lídia Ferreira, Ana Filipa Capelinha
}

\begin{abstract}
Introduction: Small bowel angiosarcomas are exceedingly rare neoplasms with unspecific symptomatology which may lead to a delay in the diagnosis and consequently a worst prognosis. Case Report: A 73-year-old male patient presented with nausea, vomiting and abdominal pain. The blood test showed a mild anemia. Computed tomography (CT) scan revealed an ileal tumor. The patient was submitted to an exploratory laparotomy and segmental enterectomy. Pathology findings described an angiosarcoma. The patient had disease progression and died after two months. Conclusion: Angiosarcomas are high grade rapidly progressive neoplasms and have a very poor prognosis with a high mortality rate. The average life expectancy is 2-6 months after diagnosis.
\end{abstract}

Keywords: Small bowel, Cancer, Primary angiosarcoma, Obstruction

Maria Olim Sousa1, Ricardo Cabrita Viveiros ${ }^{1}$, Diana Fernandes $^{1}$, Rómulo Ribeiro ${ }^{2}$, Lídia Ferreira ${ }^{2}$, Ana Filipa Capelinha ${ }^{2}$

Affiliations: ${ }^{1} \mathrm{MD}$, Hospital Dr. Nélio Mendonça - Resident, General Surgery, Funchal, Madeira, Portugal; ${ }^{2} \mathrm{MD}$, Hospital Dr. Nélio Mendonça - Consultant, General Surgery, Funchal, Madeira, Portugal.

Corresponding Author: Maria Olim Sousa, Avenida Luís de Camões № 57, Funchal, Madeira, Portugal, 9004-514; Email: mariaolimsousa@gmail.com

Received: 22 February 2017

Accepted: 21 April 2017

Published: 16 May 2017

\section{How to cite this article}

Sousa MO, Viveiros RC, Fernandes D, Ribeiro R, Ferreira L, Capelinha AF. Primary angiosarcoma of the small bowel: A case report. Case Rep Int 2017;6:21-26.

Article ID: 100037CRINTMS2017

$* * * * * * * * *$

doi:10.5348/crint-2017-37-CR-6

\section{INTRODUCTION}

Angiosarcomas account for $1-2 \%$ of soft tissue sarcomas and are preferentially localized to skin and superficial soft tissue. Rare cases are described in heart, liver, spleen and adrenal glands, being the digestive tract localization an exceptionally rare occurrence [1-3].

Malignant tumors of the small intestine make up only $1-1.6 \%$ of all gastrointestinal tract tumors.

The most widely recognized predisposing factors for angiosarcomas of skin and soft tissue are radiation and chronic lymphedema (Stewart-Treves syndrome). There is also a strong association with contact to some chemical agents such as thorium dioxide, arsenic, vinyl chloride or to foreign material introduced iatrogenically like vascular graft material or by trauma such as foreign bodies $[1,4]$.

Clinically, like other tumors of the small bowel, angiosarcomas have nonspecific symptoms including recurrent gastrointestinal bleeding, abdominal pain and nausea $[2,5-7]$. The few cases described in the literature report rapid dissemination and very reserved prognosis with average survival from two to six months after diagnosis [3,6].

The authors present a clinical case of a primary angiosarcoma of the small bowel. 


\section{CASE REPORT}

A 73-year-old male, with irrelevant personal history and no known exposure to chemical toxins, surgery, chemotherapy or radiation was admitted to the emergency department with abdominal pain in the right lower quadrant and vomiting for three days. Physical examination revealed a palpable mass in the mesogastric region of the abdomen. Laboratory testing detected a mild anemia ( $\mathrm{Hb} 11.3 \mathrm{mg} / \mathrm{dL}$ ) with no other analytic abnormalities. The computed tomography demonstrated an abdominal tumor measuring approximately $12.3 \times 11.6 \times 7 \mathrm{~cm}$ in the proximal ileum, with regional lymph nodes and a moderate amount of intra-abdominal free fluid (Figure 1).

Laparotomy showed a small bowel obstructing tumor and a minimal amount of bloody ascites. No other lesions were observed. A segmental enterectomy was performed (Figure 2). Pathological analysis revealed an angiosarcoma and immunohistochemistry shows positivity for factor VIII, CD 34, CD31 and negativity for CD 117, S100 and MITF (Figure 3). The tumor was $7 \mathrm{~cm}$ in larger axis and had metastasis in 4 of 16 nodes removed.

Due to the rarity of randomized trials and prospective studies, the management guidelines for other soft tissue sarcomas tend to be utilized when dealing with angiosarcoma. According to 7th edition of AJCC SoftTissue Sarcoma Staging System, this case was classified as pT2bN1Mo. The presence of positive nodes (N1) in Mo tumors is considered stage III.

There were no complications during the postoperative period. Adjuvant chemotherapy was decided by multidisciplinary team discussion.

One month after surgery was readmitted with abdominal pain, vomiting, ascitic abdominal distension and worsening anemia ( $\mathrm{Hb} 9.2 \mathrm{mg} / \mathrm{dL}$ ). Paracentesis was performed and $1000 \mathrm{~mL}$ of serous-hematic fluid was drained. The ascitic fluid was positive for malignant cells. CT scan showed extensive peritoneal carcinomatosis (Figure 4). Patient experienced a progressive abdominal distention, worsening of pain and anemia despite transfusions; loss of weight with severe malnutrition and rapid deterioration with multiorgan failure; he died within two months after the initial diagnosis.

\section{DISCUSSION}

The primary angiosarcoma of the small bowel like other neoplasms on this location present with nonspecific symptomatology that may include abdominal pain, nausea, vomiting, intestinal obstruction, gastrointestinal bleeding and anemia $[2,4]$.

The patient, in our case report, presented with nonspecific complaints of pain and vomiting, and had no identifiable risk factors described in the medical literature [1]. This may have been the reason for delayed diagnosis and consequent poor prognosis.
Magnetic resonance imaging (MRI) scan, computed tomography (CT) scan, abdominal X-rays and ultrasound can be used for diagnosis, but all of them have limited diagnostic utility $[5,6]$.

Immunohistochemistry is the only method to confirm the diagnosis [7]. Immunohistologically, intestinal angiosarcomas are positive for endothelial markers as CD31, CD 34, Von Willebrand factor and vascular endothelial growth factor and negative for epithelial,
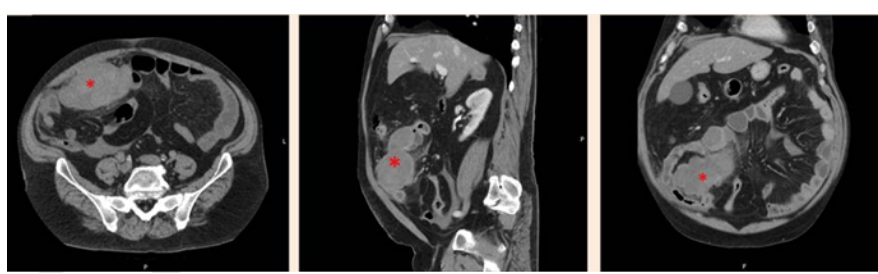

Figure 1: Computed tomography scan showing an abdominal tumor.

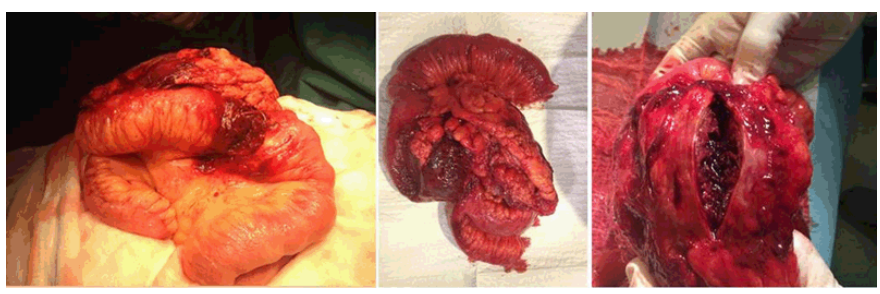

Figure 2: Laparotomy findings: small bowel obstructive tumor. A segmental enterectomy was performed.

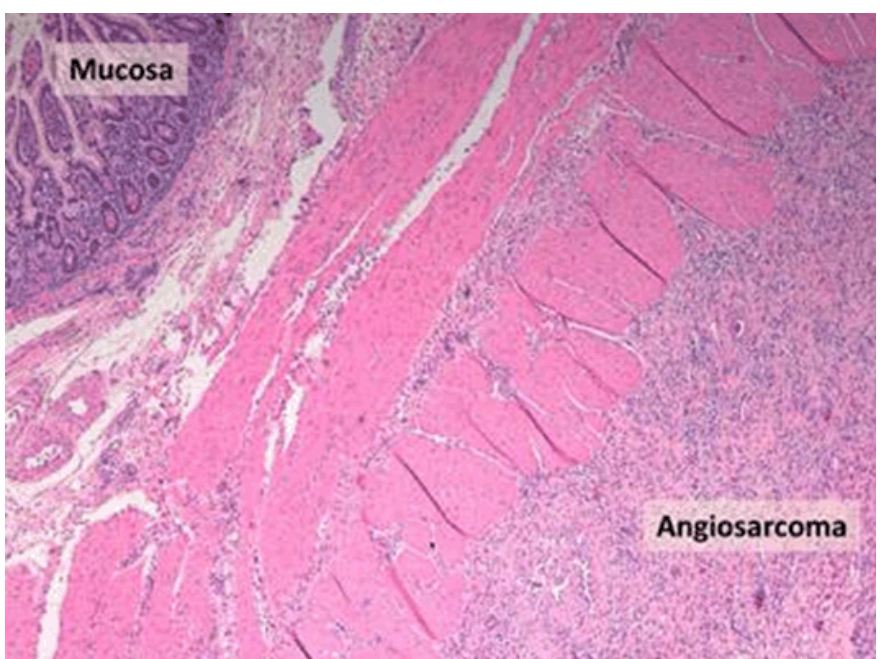

Figure 3: Histological sections of intestinal tissue observed through an optical microscope (hematoxylin eosin). Specimen showed an angiosarcoma. Immunohistologically: Factor VIII+, CD34+, CD31+, CD117-, S100- and MITF-.
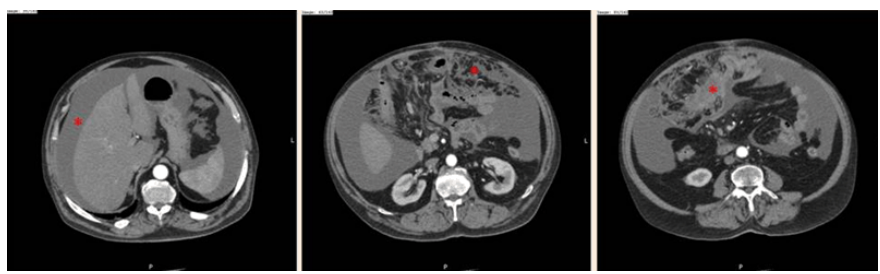

Figure 4: Computed tomography scan evidencing extensive peritoneal carcinomatosis. 
neuronal and melanocytic markers as Keratins, S-10o and HMBE-45 [1, 4, 7].

Despite its aggressive behavior, angiosarcoma of the small bowel is an extremely rare entity [3]. In a literature review only 22 cases of truly primary angiosarcoma of small intestine cases were described (Table 1) [8].
There is no established standard treatment, and treatment itself becomes difficult owing to late detection due to inaccessible localization and the nonspecific symptoms.

The attempt to treat these patients requires a multidisciplinary team that may include radiologists,

Table 1: Cases of confirmed primary angiosarcoma involving the small intestine reported in English literature

\begin{tabular}{|c|c|c|c|c|c|c|c|}
\hline Authors & $\begin{array}{l}\text { Sex/age } \\
\text { (years) }\end{array}$ & Site & $\begin{array}{l}\text { Immuno- } \\
\text { histochemical } \\
\text { staining }\end{array}$ & $\begin{array}{l}\text { History of } \\
\text { prior } \\
\text { radiation or } \\
\text { other } \\
\text { predisposing } \\
\text { factor }\end{array}$ & Presentation & Treatment & Follow-up \\
\hline $\begin{array}{l}\text { Siderits } \\
\text { et al. }\end{array}$ & $\mathrm{M} / 79$ & $\begin{array}{l}\text { Small } \\
\text { bowel }\end{array}$ & $\begin{array}{l}\text { Strongly positive for } \\
\text { CD31 }\end{array}$ & None & Obstruction & Resection & Unknown \\
\hline $\begin{array}{l}\text { Taxy and } \\
\text { Battifora }\end{array}$ & $\mathrm{M} / 64$ & $\begin{array}{l}\text { Small } \\
\text { bowel }\end{array}$ & $\begin{array}{l}\text { Positive for Factor } \\
\text { VIII, } \\
\text { collagen type IV and } \\
\text { vimentin }\end{array}$ & Not available & $\begin{array}{l}\text { Gastrointestinal } \\
\text { bleeding }\end{array}$ & Resection & $\begin{array}{l}\text { Died } 1 \text { year } \\
\text { after } \\
\text { the initial } \\
\text { diagnosis }\end{array}$ \\
\hline $\begin{array}{l}\text { Taxy and } \\
\text { Battifora }\end{array}$ & $\mathrm{F} / 57$ & $\begin{array}{l}\text { Small } \\
\text { bowel }\end{array}$ & $\begin{array}{l}\text { Positive for Factor } \\
\text { VIII, } \\
\text { collagen type IV }\end{array}$ & Not available & Not available & Resection & $\begin{array}{l}\text { Died shortly } \\
\text { after } \\
\text { surgery }\end{array}$ \\
\hline Chami et al. & $\mathrm{M} / 59$ & $\begin{array}{l}\text { Small } \\
\text { bowel }\end{array}$ & $\begin{array}{l}\text { Weakly positive for } \\
\text { factor } \\
\text { VIII-related antigen, } \\
\text { Ulex } \\
\text { europaeus I antigen } \\
\text { and } \\
\text { cytokeratin }\end{array}$ & None & $\begin{array}{l}\text { Gastrointestinal } \\
\text { bleeding, } \\
\text { bowel } \\
\text { obstruction, } \\
\text { anorexia } \\
\text { and weight loss }\end{array}$ & $\begin{array}{l}\text { Resection and } \\
\text { transfusions }\end{array}$ & $\begin{array}{l}\text { Died on the } \\
\text { 11th } \\
\text { day after } \\
\text { surgery }\end{array}$ \\
\hline $\begin{array}{l}\text { Ordonez } \\
\text { et al. }\end{array}$ & $\mathrm{M} / 80$ & $\begin{array}{l}\text { Small } \\
\text { bowel }\end{array}$ & $\begin{array}{l}\text { Positive } \\
\text { immunoreaction } \\
\text { for FVIII-RAG }\end{array}$ & None & $\begin{array}{l}\text { Anemia, undue } \\
\text { tiredness } \\
\text { and weakness }\end{array}$ & Resection & $\begin{array}{l}\text { Died on the } \\
\text { 2oth } \\
\text { postoperative } \\
\text { day }\end{array}$ \\
\hline $\begin{array}{l}\text { Hwang } \\
\text { et al. }\end{array}$ & $\mathrm{F} / 60$ & $\begin{array}{l}\text { Small } \\
\text { bowel }\end{array}$ & $\begin{array}{l}\text { Positive for Ulex } \\
\text { europaeus agglutinin } 1\end{array}$ & $\begin{array}{l}\text { History of } \\
\text { radiotherapy }\end{array}$ & $\begin{array}{l}\text { Diffuse } \\
\text { abdominal pain }\end{array}$ & Resection & $\begin{array}{l}\text { Died } 2 \\
\text { months } \\
\text { after } \\
\text { discharge }\end{array}$ \\
\hline $\begin{array}{l}\text { Mohammed } \\
\text { et al. }\end{array}$ & $\mathrm{F} / 25$ & $\begin{array}{l}\text { Small } \\
\text { bowel }\end{array}$ & Not available & None & $\begin{array}{l}\text { Intermittent } \\
\text { abdominal } \\
\text { pain, weight loss, } \\
\text { abdominal } \\
\text { distension, } \\
\text { hematemesis } \\
\text { and malaena }\end{array}$ & Resection & $\begin{array}{l}\text { Died on the } \\
\text { 11th } \\
\text { day after } \\
\text { surgery }\end{array}$ \\
\hline $\begin{array}{l}\text { Fraiman } \\
\text { et al. }\end{array}$ & $\mathrm{M} / 85$ & $\begin{array}{l}\text { Small } \\
\text { bowel }\end{array}$ & $\begin{array}{l}\text { Strong positivity for } \\
\text { vimentin and CD } 31 \text {; } \\
\text { focal positivity for } \\
\text { factor } \\
\text { VIII and CD34 }\end{array}$ & None & $\begin{array}{l}\text { Weight loss, } \\
\text { anemia, } \\
\text { weakness and } \\
\text { abdominal } \\
\text { pain }\end{array}$ & $\begin{array}{l}\text { Resection and } \\
\text { thalidomide }\end{array}$ & Not available \\
\hline Selk et al. & $\mathrm{M} / 57$ & $\begin{array}{l}\text { Small } \\
\text { bowel }\end{array}$ & Not available & $\begin{array}{l}\text { History of } \\
\text { radiation } \\
\text { therapy }\end{array}$ & $\begin{array}{l}\text { Progressive } \\
\text { abdominal } \\
\text { distention and } \\
\text { shortness } \\
\text { of breath }\end{array}$ & Resection & $\begin{array}{l}\text { Died } 4 \\
\text { months } \\
\text { after surgery }\end{array}$ \\
\hline Berry et al. & $\mathrm{M} / 51$ & $\begin{array}{l}\text { Small } \\
\text { bowel }\end{array}$ & $\begin{array}{l}\text { Positive for Ulex } \\
\text { europaeus and } \\
\text { vimentin }\end{array}$ & $\begin{array}{l}\text { History of } \\
\text { 3-year } \\
\text { irradiation }\end{array}$ & Peritonitis & $\begin{array}{l}\text { Resection, } \\
\text { adriamycin } \\
\text { and } \\
\text { dacarbazine }\end{array}$ & $\begin{array}{l}\text { Died } 5 \\
\text { months after } \\
\text { initial } \\
\text { presentation }\end{array}$ \\
\hline
\end{tabular}




\begin{tabular}{|c|c|c|c|c|c|c|c|}
\hline Khalil et al. & $\mathrm{M} / 68$ & $\begin{array}{l}\text { Small } \\
\text { bowel }\end{array}$ & $\begin{array}{l}\text { Strongly positive for } \\
\text { CD } 31, \text { CD } 34 \text { and } \\
\text { vimentin }\end{array}$ & $\begin{array}{l}30 \text { year history } \\
\text { of heavy } \\
\text { occupational } \\
\text { exposure } \\
\text { to radiation and } \\
\text { polyvinyl } \\
\text { chloride }\end{array}$ & $\begin{array}{l}\text { Gastrointestinal } \\
\text { bleeding } \\
\text { and melaena }\end{array}$ & Resection & $\begin{array}{l}\text { Died } 6 \\
\text { months after } \\
\text { initial } \\
\text { presentation }\end{array}$ \\
\hline Suzuki et al. & $\mathrm{F} / 61$ & Ileum & $\begin{array}{l}\text { Positive for factor } \\
\text { VIII-related antigen } \\
\text { and Ulex europaeus } \\
\text { agglutinin } 1\end{array}$ & $\begin{array}{l}20 \text { year history } \\
\text { of } \\
\text { radiotherapy }\end{array}$ & Abdominal pain & $\begin{array}{l}\text { Resection and } \\
\text { intraabdominal } \\
\text { cisplatin }\end{array}$ & $\begin{array}{l}\text { Died } 1 \text { year } \\
\text { after } \\
\text { initial } \\
\text { presentation }\end{array}$ \\
\hline $\begin{array}{l}\text { Delvaux } \\
\text { et al. }\end{array}$ & $\mathrm{M} / 67$ & $\begin{array}{l}\text { Small } \\
\text { bowel }\end{array}$ & $\begin{array}{l}\text { Positive for CD 31, } \\
\text { CD 34, factor VIII- } \\
\text { related } \\
\text { antigen and keratin }\end{array}$ & Not available & $\begin{array}{l}\text { Weight loss, } \\
\text { intermittent } \\
\text { severe abdominal } \\
\text { pain } \\
\text { and melaena }\end{array}$ & Resection & $\begin{array}{l}\text { Died } 3 \\
\text { months } \\
\text { after } \\
\text { diagnosis }\end{array}$ \\
\hline $\begin{array}{l}\text { Policarpio- } \\
\text { Nicolas } \\
\text { et al. }\end{array}$ & $\mathrm{F} / 51$ & $\begin{array}{l}\text { Small } \\
\text { bowel }\end{array}$ & $\begin{array}{l}\text { Positive for CD } 31, \mathrm{CD} \\
34 \\
\text { and factor VIII-related } \\
\text { antigen }\end{array}$ & $\begin{array}{l}\text { History of } \\
\text { irradiation }\end{array}$ & Abdominal pain & Resection & $\begin{array}{l}\text { Died } 10 \\
\text { months } \\
\text { after } \\
\text { laparotomy }\end{array}$ \\
\hline $\begin{array}{l}\text { Hansen } \\
\text { et al. }\end{array}$ & $\mathrm{F} / 76$ & $\begin{array}{l}\text { Small } \\
\text { bowel }\end{array}$ & $\begin{array}{l}\text { Positive for factor VIII } \\
\text { and } \\
\text { vimentin }\end{array}$ & $\begin{array}{l}\text { History of } \\
\text { irradiation }\end{array}$ & $\begin{array}{l}\text { Watery diarrhea, } \\
\text { vomiting, } \\
\text { weight loss and } \\
\text { abdominal } \\
\text { pain }\end{array}$ & Resection & $\begin{array}{l}\text { Died } 5 \\
\text { months } \\
\text { after } \\
\text { operation }\end{array}$ \\
\hline Aitola et al. & $\mathrm{F} / 50$ & $\begin{array}{l}\text { Small } \\
\text { bowel }\end{array}$ & $\begin{array}{l}\text { Positive for CD } 31, \mathrm{CD} \\
34 \\
\text { and factor VIII-related } \\
\text { antigen }\end{array}$ & $\begin{array}{l}\geq 10 \text { year history } \\
\text { of } \\
\text { radiotherapy }\end{array}$ & $\begin{array}{l}\text { Intestinal } \\
\text { obstruction }\end{array}$ & $\begin{array}{l}\text { Resection } \\
\text { followed } \\
\text { by combination } \\
\text { chemotherapy } \\
\text { with } \\
\text { doxorubicin }\end{array}$ & $\begin{array}{l}1 \text { year and } 9 \\
\text { months after } \\
\text { diagnosis, } \\
\text { she } \\
\text { was alive }\end{array}$ \\
\hline Ogawa et al. & $\mathrm{M} / 36$ & $\begin{array}{l}\text { Small } \\
\text { bowel }\end{array}$ & $\begin{array}{l}\text { Positive for factor } \\
\text { VIII-related antigen }\end{array}$ & Not available & $\begin{array}{l}\text { Abdominal pain } \\
\text { and } \\
\text { nausea }\end{array}$ & Resection & Not available \\
\hline Liu et al. & $\mathrm{F} / 39$ & $\begin{array}{l}\text { Terminal } \\
\text { ileum }\end{array}$ & $\begin{array}{l}\text { Positive for CD31 } \\
\text { and CD34 }\end{array}$ & None & $\begin{array}{l}\text { Increasing right } \\
\text { iliac fossa } \\
\text { pain, abdominal } \\
\text { bloating } \\
\text { and vomiting }\end{array}$ & $\begin{array}{l}\text { Resection and } \\
\text { chemotherapy }\end{array}$ & Not available \\
\hline $\begin{array}{l}\text { Kelemen } \\
\text { et al. }\end{array}$ & $\mathrm{M} / 76$ & $\begin{array}{l}\text { Small } \\
\text { bowel }\end{array}$ & Positive for CD31 & None & $\begin{array}{l}\text { Abdominal pain } \\
\text { and } \\
\text { fatigue }\end{array}$ & Resection & $\begin{array}{l}\text { Died of } \\
\text { cardiac } \\
\text { arrest on the } \\
9 \text { th } \\
\text { day after } \\
\text { surgery }\end{array}$ \\
\hline $\begin{array}{l}\text { Fohrding } \\
\text { et al. }\end{array}$ & $\mathrm{M} / 84$ & $\begin{array}{l}\text { Small } \\
\text { bowel }\end{array}$ & $\begin{array}{l}\text { Positive for CD31, } \\
\text { cytokeratin and } \\
\text { vimentin; } \\
\text { slightly weaker for } \\
\text { CD34; } \\
\text { Focally positive for } \\
\text { factor VIII }\end{array}$ & Not available & $\begin{array}{l}\text { Gastrointestinal } \\
\text { bleeding }\end{array}$ & $\begin{array}{l}\text { Resection, } \\
\text { adjuvant } \\
\text { chemotherapy } \\
\text { with } \\
\text { paclitaxel and } \\
\text { transfusion }\end{array}$ & Not available \\
\hline $\begin{array}{l}\text { Grewal } \\
\text { et al. }\end{array}$ & $\mathrm{M} / 73$ & $\begin{array}{l}\text { Small } \\
\text { bowel }\end{array}$ & Positive for CD31 & None & $\begin{array}{l}\text { Gastrointestinal } \\
\text { bleeding, } \\
\text { weakness and } \\
\text { melaena }\end{array}$ & Resection & $\begin{array}{l}\text { Died within } 4 \\
\text { months of the } \\
\text { diagnosis }\end{array}$ \\
\hline $\begin{array}{l}\text { Qingquianq } \\
\text { Ni et al. }\end{array}$ & $\mathrm{M} / 33$ & $\begin{array}{l}\text { Small } \\
\text { bowel } \\
\text { Liver } \\
\text { metastasis }\end{array}$ & $\begin{array}{l}\text { Positive for } \\
\text { CD31 and vimentin }\end{array}$ & None & $\begin{array}{l}\text { Abdominal pain, } \\
\text { vomiting, weight } \\
\text { loss, fatigue, fever }\end{array}$ & $\begin{array}{l}\text { Resection, } \\
\text { adjuvant } \\
\text { chemotherapy }\end{array}$ & $\begin{array}{l}\text { Died on 27th } \\
\text { postoperative } \\
\text { day }\end{array}$ \\
\hline
\end{tabular}


pathologists, surgical oncologists, medical oncologists and radiation oncologists. Although the cornerstone of the treatment is surgical complete resection when possible to achieve maximal locoregional control, treatment often includes palliative resection of the bleeding or obstructing lesions, chemotherapy, radiotherapy and best supportive care which may include massive blood transfusions [3].

In 1999, Aitola et al. reported a case of a small bowel tumor resection followed by combination chemotherapy with doxorubicin which survived one year and nine months after diagnosis [9]. The patient described had 14 years previously undergone total hysterectomy and salpingo-oophorectomy for a stage I adenocarcinoma of the uterine corpus and received 55.6 Gy external radiation therapy to the lower pelvis. In May 1997, at the age of 50 years, she was again admitted to hospital due to repeated symptoms of intestinal obstruction. Complementary study demonstrated a constant 5 -cmlong stricture at the terminal ileum. Laparotomy revealed a $20 \mathrm{~cm}$ long segment of thickened terminal ileum, an extended ileocecal resection was performed. The patient received 6 adjuvant doses of doxorubicin (110 $\mathrm{mg}$ ). Relaparotomy was undertaken one year and nine months after diagnosis of the angiosarcoma from the operative specimen, and this showed wide intra-abdominal spread and retroperitoneal recurrence. This case is the one with the highest survival described in literature in patients with this disease. Most patients die within a few months after diagnosis with an average survival from two to six months after diagnosis secondary to refractory bleeding and disease progression $[2,3,6,10-13]$.

\section{CONCLUSION}

Angiosarcoma of the small bowel is an exceptionally aggressive and rare entity with very poor prognosis. Early diagnosis is a challenge due to the nonspecific symptoms. Imaging studies can be extremely important in timely finding these lesions, but high clinical suspicion based on clinical history is necessary for diagnosis. There are no defined guidelines or demonstrated efficacy of adjuvant treatment due to the low incidence of this pathology, thus, the multidisciplinary approach of these patients is of utmost importance.

$* * * * * * * * *$

\section{Acknowledgements}

We are thankful to Emanuele Parodi, Hospital Dr. Nélio Mendonça, Consultant, General Surgery, Funchal, Madeira, Portugal, and Fernando Jasmins, Hospital Dr. Nélio Mendonça, Consultant, General Surgery, Funchal, Madeira, Portugal for their help and support in preparing the manuscript.

\section{Author Contributions}

Maria Olim Sousa - Substantial contributions to conception and design, Acquisition of data, Analysis and interpretation of data, Drafting the article, Revising it critically for important intellectual content, Final approval of the version to be published

Ricardo Cabrita Viveiros - Substantial contributions to conception and design, Acquisition of data, Analysis and interpretation of data, Drafting the article, Revising it critically for important intellectual content, Final approval of the version to be published

Diana Fernandes - Substantial contributions to conception and design, Acquisition of data, Analysis and interpretation of data, Drafting the article, Revising it critically for important intellectual content, Final approval of the version to be published

Rómulo Ribeiro - Substantial contributions to conception and design, Acquisition of data, Analysis and interpretation of data, Drafting the article, Revising it critically for important intellectual content, Final approval of the version to be published

Lídia Ferreira - Substantial contributions to conception and design, Acquisition of data, Analysis and interpretation of data, Drafting the article, Revising it critically for important intellectual content, Final approval of the version to be published

Ana Filipa Capelinha -Substantial contributions to conception and design, Acquisition of data, Analysis and interpretation of data, Drafting the article, Revising it critically for important intellectual content, Final approval of the version to be published

\section{Guarantor}

The corresponding author is the guarantor of submission.

\section{Conflict of Interest}

Authors declare no conflict of interest.

\section{Copyright}

(C) 2017 Maria Olim Sousa et al. This article is distributed under the terms of Creative Commons Attribution License which permits unrestricted use, distribution and reproduction in any medium provided the original author(s) and original publisher are properly credited. Please see the copyright policy on the journal website for more information.

\section{REFERENCES}

1. Weiss SW, Goldblum JR, Folpe AL. Enzinger \& Weiss's Soft Tissue Tumors. 6ed. Philadelphia Saunders; 2013. p. 703-32.

2. Lopes RH, Resende FAM, Fraga JBP, et al. Angiosarcoma of small intestine: Case report and literature review. J Bras Patol Med Lab 2016;52(5):345-8.

3. Grewal JS, Daniel AR, Carson EJ, Catanzaro AT, Shehab TM, Tworek JA. Rapidly progressive metastatic multicentric epithelioid angiosarcoma of the small bowel: A case report and a review of literature. Int J Colorectal Dis 2008 Aug;23(8):74556. 
4. Zemheri E, Engin P, Ozkanli S, Ozemir IA. Primary angiosarcoma of small intestine presenting with intestinal perforation: A case report. J Med Cases 2014;5(2):113-5.

5. Mohammed A, Aliyu HO, Liman AA, Abdullahi K, Abubakar N. Angiosarcoma of the small intestine. Ann Afr Med 2011 Jul-Sep;10(3):246-8.

6. Young RJ, Brown NJ, Reed MW, Hughes D, Woll PJ. Angiosarcoma. Lancet Oncol 2010 Oct;11(10):98391.

7. Aziz MT, Tabrez MO. Angiosarcoma of small intestine presenting with intestinal obstruction. Int Surg $\mathrm{J}$ 2016;3(2):956-8.

8. Ni Q, Shang D, Peng H, Roy M, Liang G, Bi W, Gao $\mathrm{X}$. Primary angiosarcoma of the small intestine with metastasis to the liver: A case report and review of the literature. World J Surg Oncol 2013 Sep 25;11:242.

9. Aitola P, Poutiainen A, Nordback I. Small-bowel angiosarcoma after pelvic irradiation: A report of two cases. Int J Colorectal Dis 1999 Dec;14(6):308-10.
10. Zacarias Föhrding L, Macher A, Braunstein S, Knoefel WT, Topp SA. Small intestine bleeding due to multifocal angiosarcoma. World J Gastroenterol 2012 Nov 28;18(44):6494-500.

11. Allison KH, Yoder BJ, Bronner MP, Goldblum JR, Rubin BP.Angiosarcoma involving the gastrointestinal tract: A series of primary and metastatic cases. Am J Surg Pathol 2004 Mar;28(3):298-307.

12. Kelemen $\mathrm{K}, \mathrm{Yu}$ QQ, Howard L. Small intestinal angiosarcoma leading to perforation and acute abdomen: A case report and review of the literature. Arch Pathol Lab Med 2004 Jan;128(1):95-8.

13. Taxy JB, Battifora H. Angiosarcoma of the gastrointestinal tract a report of three cases. Cancer 1988 Jul 1;62(1):210-6.
Access full text article on other devices

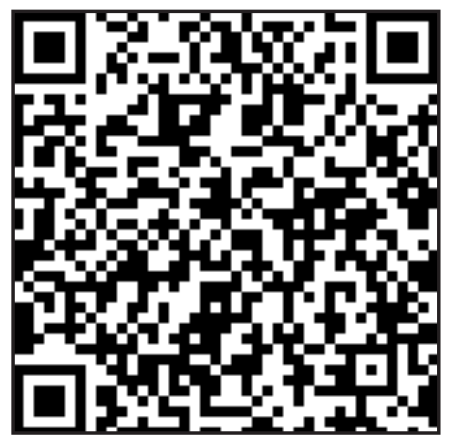

Access PDF of article on other devices

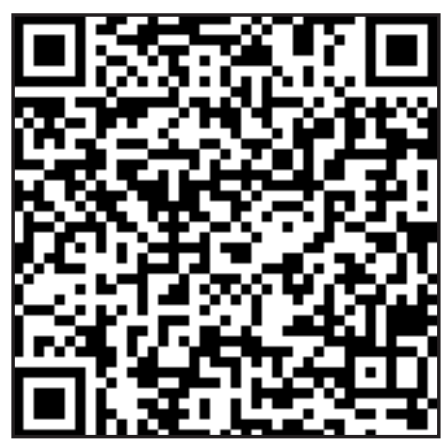

